\title{
A RASURA DA LETRA E A EXPLOSÃO DO SEMBLANTE*
}

Andrea Menezes Masagão

Psicanalista; doutora em Psicologia Clínica pela USP.

RESUMO: Investiga-se a construção de um registro que representa o sujeito, a partir do ato de circulação da escrita no espaço público. Paulo 'despacha' no espaço público o que nomeia como "bombas de efeito moral”. Suas bombas são feitas de imagens, letras e restos descartados no lixo como rótulos e embalagens. Trata-se de uma escrita que faz furo na representação, quebrando a unidade de sentido e revelando a materialidade da letra. Escrita que provoca um curto circuito na função mensageira da linguagem e faz borda nos discursos.

Palavras-chave: Psicanálise, letra, traço, rasura, psicose.

ABSTRACT: The scraping of the letter and the semblant's explosion. The aim of this article is the inquiry of the construction of a register that represents the subject, with a starting point at the circulation of the writing in the public space. Paulo "dispatches", in the public space, what he calls "moral bombs". His bombs are made of images, written characters and discarded material he finds in trash bins - such as labels and packages. This type of writing bores a hole in representation, breaking the unity of sense and revealing the materiality of the letter. This writing short-circuits the message function of language and remains in the margins of discourses.

Keywords: Psychoanalysis, letter, stroke, erasure, psychosis.

\section{O TOQUE}

Esse trabalho tem como objetivo a investigação da construção de um registro psíquico, que representa e diferencia o sujeito, a partir do ato de circulação da escrita no espaço público. Serão utilizados os conceitos de traço e de letra, especialmente as elaborações de Lacan realizadas no seminário $A$ identificação (1961-62/2003) e no texto Lituraterra (1971/2003).

\footnotetext{
* Este texto faz parte da tese de doutorado "A impressão da marca e a rasura do traço na escrita das margens", defendida em 2007 no Departamento de Psicologia Clínica da USP, com orientação da prof. Dra. Jussara Falek Brauer.
} 
Trata-se da escrita de Paulo, um homem de meia idade, magro e quase sempre bem vestido. Ele mora sozinho em um apartamento conjugado no Centro da cidade de São Paulo. As janelas estão todas forradas com folhas de papelão, impedindo que olhares intrusos invadam sua privacidade. Paulo levanta cedo todas as manhãs e faz longas caminhadas pelas ruas do bairro. No entanto, nem sempre se trata de um passeio tranqüilo, pois ele é permanentemente convocado a tocar os símbolos que encontra pelo caminho. Assim, ao passar por um carro estacionado na calçada, toca com o dedo indicador um adesivo pregado no vidro com os dizeres; "todas as mulheres são lindas". Toca da mesma maneira um homem vestido com uma camiseta na qual está escrito “No stress” e também o crucifixo de madeira pendurado no pescoço de uma freira que passa por ele.

O caminhar de Paulo é sinuoso, marcado pelo encontro com os símbolos que habitam os espaços da cidade e invadem seu corpo convocando o toque. Já o encontro com o corpo dos que passam e cruzam seu caminho nas calçadas deve ser evitado. Nesse jogo que se estabelece entre o toque dos símbolos e o desvio do toque dos corpos anônimos, Paulo decerto não passa despercebido pelas ruas por onde caminha. Ele promove uma espécie de inversão, fazendo do símbolo algo que pode ser tocado, enquanto o corpo permanece intocável. Temos aqui uma primeira hipótese a respeito do registro através do qual Paulo busca representar-se e ao mesmo tempo diferenciar-se, hipótese que aponta para a construção de um registro no qual essa espécie de encenação corporal se faz necessária. Por meio dela Paulo busca defender-se da posição de objeto, ao se colocar em uma posição ativa, ou seja, tocando; ao mesmo tempo, protege o corpo do toque invasivo do Outro sem falta, ao fazer do seu corpo algo que não pode ser tocado.

O par ‘tocar/ser tocado’ coloca em causa uma possibilidade de defesa contra a contaminação, a indiferenciação entre símbolo e corpo. No seminário Os quatro conceitos fundamentais da psicanálise (1964/1998), Lacan trabalha o que Freud distingue como os quatro termos da pulsão: o impulso (Drang), a fonte (Quelle), o alvo (Ziel) e o objeto. Lacan retoma esses quatro termos propondo a pulsão como uma montagem na qual se articulam a sexualidade, o sujeito e a linguagem; articulação que aponta para o laço do sujeito ao Outro e para a perda que todo o ser humano sofre como ser sexuado, ser de linguagem. O corpo pulsional é um corpo sustentado nos orifícios recortados pelo Outro. O olhar e a voz do Outro possibilitam a unidade do corpo e o reconhecimento da criança nessa imagem: o olhar — signo do assentimento da escolha de Amor do Outro, traço distintivo - é o que sustenta na descontinuidade simbólica a unidade imaginária do eu; a voz autoriza o reconhecimento da imagem como própria - "Você é esse que está aí no espelho”. A junção do olhar e da voz é o que regula a dialética entre o corpo despedaçado e o corpo unificado. 
Essa dialética implica a alienação em que palavra e imagem permanecem coladas, e é preciso, então, separar a palavra da imagem, o corpo do gozo, o significante da significação. Na separação, o objeto da pulsão está entre o corpo do bebê e o corpo do Outro, espaço ex-timo que tem estrutura de borda. Lacan aponta no jogo infantil que ficou conhecido entre os analistas como fort-da, uma matriz do sujeito a partir da produção em ato de uma memória, um registro que se produz a partir de uma perda, uma separação (LACAN, 1964/1998). O jogo, repetido compulsivamente, visa ao que não está representado; ele cria em ato o objeto que se perde, que se destaca do corpo, mas que é parte do corpo, o objeto a, objeto parcial da pulsão. É nesse sentido que a repetição da saída da mãe não representa a mãe a partir de sua ausência, mas causa a divisão do sujeito; aponta tanto para a criação como para a perda, pois, a cada vez que a criança cria o carretel-objeto, ela o perde.

No entanto, não é suficiente apenas o ato, a separação, para que o registro do sujeito possa ter lugar. É necessário que nesse lugar da queda do objeto pulsional inscreva-se um traço do sujeito aonde o significante vem se alojar. É necessário que além do ato exista a suposição de um sujeito, o laço do sujeito ao Outro, laço que permite que o traço que se inscreve no lugar da queda do objeto possa ser lido por um Outro. É o endereçamento do sujeito ao Outro o que possibilita uma leitura do traço que se repete. A separação/diferenciação do Outro implica que o sujeito possa circular do registro da passividade para o registro da atividade. É o que Freud (1908/1981) observa nas brincadeiras infantis em que a criança realiza de forma ativa, com seus brinquedos, o que sofreu passivamente nas primeiras relações com a mãe.

Nessas relações primeiras, o corpo do bebê é o lugar de uma série de cuidados por parte da mãe, e é nesses cuidados que Freud encontra a raiz das fantasias de sedução. Na circulação passividade-atividade o sujeito pode passar da posição de objeto para a posição de sujeito, ou mesmo sustentar ativamente a posição passiva de objeto causa do desejo do Outro. Podemos supor então que o par tocável/intocável posto em ato na encenação corporal de Paulo aponta o par passivo/ativo, nossos organizadores pulsionais. No entanto, o toque não é a única estratégia adotada por ele diante da indiferenciação entre símbolo e corpo, como veremos, a letra é também uma estratégia.

\section{APONTAMENTOS SOBRE A LETRA}

Antes de abordarmos os efeitos da letra na construção do registro visado por Paulo, vamos nos ater a um breve percurso das elaborações de Lacan destacando momentos em que o conceito de letra é trabalhado. No seminário sobre a Carta roubada, Lacan (1956/1998) trabalha um conto de Edgar Allan Poe e destaca a heterogeneidade de registros que incidem sobre a letra. A letra letter/carta porta 
uma mensagem que se desloca, ora revelando-se, ora ocultando-se, entre diferentes personagens do conto e aponta para a incidência da repetição da cadeia significante. O deslocamento é determinado pelo lugar que vem a ocupar entre os personagens esse significante puro que é a carta roubada. A letra litter/lixo designa outro registro, que difere da letra tomada como significante cuja função aponta para a transmissão de uma mensagem. A litter aponta a materialidade da letra:

"E, com efeito, voltando a nossos policiais, como poderiam eles apoderar-se da carta, eles que a apanharam no lugar onde estava escondida? Naquilo que reviravam entre os dedos, que outra coisa seguravam eles senão o que não correspondia à descrição que tinham dela? A letter, a litter, uma carta, uma letra, um lixo. Fizeram-se trocadilhos, no cenáculo de Joyce, com a homofonia dessas duas palavras em inglês. A espécie de objeto que os policiais manipulam nesse momento, tampouco lhes revela sua outra natureza por estar apenas meio rasgada." (LACAN, 1956/ 1998, p.28)

Lacan aponta essa outra natureza da carta/letra chamando a atenção sobre aquilo que ultrapassa sua aparente função de transportar e transmitir uma mensagem. Segundo Mandil (2003), Dupin, o detetive chamado para encontrar a carta roubada, só consegue recuperá-la porque, diferente dos policiais que a procuram em vão, ele consegue perceber essa dupla natureza da carta/letra. O fato de uma carta não estar inteiramente do lado da mensagem, possuindo também uma materialidade, e sendo, portanto, manuseável, passível de ser esquecida, rasgada, guardada, adulterada ou tratada como detrito. Não é a mesma coisa buscar uma carta/letra levando em consideração a sua dimensão da mensagem, ou seja, a letra como elemento de um sistema significante, ou buscá-la tomando a sua materialidade, a sua relação ao objeto.

Em Lituraterra (1971/2003), Lacan enfatiza a articulação entre a letra e o objeto ao apontar a função litoral da letra. A letra-litoral faz furo no saber e presentifica a ausência de uma medida comum entre os diferentes registros que a determinam:

"A borda do furo no saber, não seria o que ela desenha? E como a psicanálise poderia negar esse furo - uma vez que a letra diz ao pé da letra através de sua boca, ela não deveria desconhecê-lo — , como poderia ela negar esse furo, se para preenchê-lo ela recorre aí à invocação do gozo." (1971/2003, p.18)

Como litoral, a letra ao mesmo tempo conjuga e distingue campos heterogêneos e revela a descontinuidade existente entre eles: ela liga, une, promove encontros... "O significante deriva apenas da instância S; mas a letra vincula RSI que são mutuamente heterogêneos” (MILNER, 1996, p.105). A letra-litoral 
decerto não é a letra-fetiche encarnada nas cartas que Gide endereçava a sua amada Madeleine. Embora a análise realizada por Lacan em seu texto Juventude de Gide ou a letra e o desejo (1958/1998) permita uma aproximação entre a letra-fetiche e a letra-litter, já que ambas remetem à letra tomada na sua relação ao objeto, a letra-litoral não tapa o lugar vazio do objeto, e, nesse sentido, ela se diferencia do significante na sua função de semblante ou do objeto na sua função de fetiche. Como veremos, o uso que Paulo faz da letra se aproxima da função da letra-litoral apontada por Lacan.

\section{MULHERES E LETRAS}

Durante suas caminhadas diárias, Paulo coleta os mais diferentes símbolos; um papel de bala amarelo forte deixado em cima do balcão de uma padaria, um tíquete de metrô jogado na calçada, a carteira de estudante encontrada entre sacos de lixo. Ele recolhe os restos descartados no espaço público para utilizá-los na manufatura de suas bombas de papel. Além dos restos alheios encontrados nos mais diversos locais, ele utiliza também os restos que sobram de seu quotidiano: o tubo de uma pasta de dentes, o bilhete de aposta da loteria, o tíquete da roupa que foi para a lavanderia. Livros e revistas - a maioria comprada em sebos no Centro da cidade — também são utilizados para a fabricação de suas bombas. É durante a noite que Paulo realiza seu trabalho, utilizando os materiais coletados em suas caminhadas diurnas. Sentado sempre no mesmo lugar diante de sua mesa, ele inicia um curioso processo de transformação. As letras impressas no papel são riscadas com movimentos circulares e ininterruptos até desaparecerem completamente, submersas sob a tinta azul de sua caneta esferográfica.

As imagens estampadas nas folhas de revista são todas assinaladas com três traços paralelos que, segundo Paulo, simbolizam a Santíssima Trindade: o Pai, o Filho e o Espírito Santo. Os restos (papéis de bala, o tíquete do metrô, o bilhete de loteria, etc.) também são assinalados com os três traços. Para finalizar, Paulo marca o papel com o que ele nomeia sua insígnia: um misto de letra e desenho que simboliza o vôo de um pássaro. A seguir, coloca tudo - letras submersas, imagens assinaladas e restos encontrados no espaço público — em uma folha de jornal cuidadosamente enrolada na forma de um canudo. O canudo é amarrado com um pedaço de barbante para depois ser despachado no espaço público. Paulo diz que se trata de uma bomba de efeito moral, como aquelas jogadas contra os manifestantes em tempos de ditadura. Ele se diz um guerrilheiro urbano que procura no espaço público um alvo para jogar sua bomba. São alvos aleatórios: a janela aberta de um carro parado no trânsito, uma loja de ferragens, um carro do Exército, um caminhão de lixo, a portaria de um prédio chamado D. Pedro I, a embaixada da Itália. A única regra é não repetir o alvo... 
Paulo iniciou seu trabalho com as letras aos 17 anos, o que coincide com o encontro com uma prostituta. Do encontro com a mulher de todos os homens, mulher pública, Paulo iniciou uma série. Nomeou essa primeira mulher namorada mitológica. A partir desse encontro começou a desfolhar livros e revistas e a rasgar as letras e as imagens com o objetivo de transformar a substância em essência; a matéria, em espírito; o material, em imaterial. Quando fez 23 anos, foi aposentado por invalidez e localizou aí o momento de ruptura em que saiu da sociedade. Momento em que o exterior se fechou e ele se voltou para o interior, para o que chamou de uma dimensão espiritual da existência. O trabalho com as letras é realizado como um misticismo, uma forma de aprimorar seu espírito.

O encontro com uma segunda mulher, a quem nomeou noiva teológica, ocorreu nessa mesma época e forneceu-lhe uma prova da efetividade de seu trabalho: Paulo encontrou na revista Playboy a imagem de Bruna Lombardi saindo da piscina. Desejou para si um tipo físico como aquele para se relacionar. Começou a rezar e recebeu um mandamento que lhe veio sob a forma de uma revelação; foi-lhe dito que ele devia escrever em cima da imagem da mulher as seguintes palavras que evocavam a Santíssima Trindade: Pai-vida, Filho-amor, Espírito Santo-razão.

Em seguida ele rasgou a imagem para transformar a matéria em essência e apropriar-se da essência de Bruna Lombardi. Uma semana depois se deparou com uma mulher idêntica à da foto; um xerox, cuja única diferença era não ter os olhos verdes da Bruna. Convidou-a para sair, sustentado na certeza de que não se tratava de um encontro ao acaso e sim da efetividade de seu ato. Manteve com ela uma correspondência por meio de cartas poéticas nas quais produziu rimas que recolheu de livros. Ele tirou xerox das cartas e enviou para ela as cópias, guardando os originais. Depois utilizou os originais em seu trabalho, rasgando-os.

Um ano depois, conheceu uma terceira mulher — também prostituta. Nomeou-a esposa mística. Resolveu simular uma identidade e disse a ela que trabalhava como topógrafo. No entanto, não conseguiu sustentar-se durante muito tempo nesse disfarce diante da mulher e confessou a ela seu verdadeiro trabalho, o trabalho místico que realizava com as letras e imagens. Diante de tal confissão, acabou perdendo a mulher e mergulhou em um momento de terror. Para conservá-la de alguma maneira, realizou um casamento simbólico. Escreveu seu nome junto ao dela em uma fotografia e ateou fogo. O casamento simbólico permitiu-lhe manter a mulher em outro lugar; um lugar onde nada podia ser tocado, mas onde tudo podia ser conservado. Nas palavras de Paulo:

"Eu não encontrava uma saída. Aí tive que renunciar àquela mulher. Esse foi um momento de terror. Eu a perdi. Então queria conservá-la e fiz um casamento simbólico; peguei sua fotografia e escrevi o meu nome e o dela e coloquei fogo. Foi uma maneira de dominar aquele sentimento de perda, dominar o próprio 
desejo. O desejo que as pessoas têm quando se apaixonam, pois a vida deixa de existir sem a outra pessoa. Essa tempestade pela qual eu passei consegui dominar através do fogo. Mas mesmo assim eu fiquei me depurando muito tempo, eu estava condicionado fisicamente a ela. Eu ainda fiquei sonhando que ela ia voltar, durante um ano ou dois. Até aquele amor morrer..."

Para melhor compreendermos os efeitos que o trabalho com a letra tem na construção de um registro a partir do qual Paulo visa representar-se e ao mesmo tempo diferenciar-se, vamos estabelecer uma diferença de lugares: o lugar da produção/escritor e o lugar do público/leitor. Podemos supor que do lugar da produção/ escritor o trabalho com a letra surge para Paulo como efeito do encontro com o sexo feminino. Será que a contagem que ele inaugura ao fazer série das mulheresprostitutas permite a possibilidade do estabelecimento de um intervalo, uma distância, uma medida em relação ao Outro primordial? Podemos supor que a mulher apresenta-se na economia pulsional que organiza a subjetividade de Paulo como um resto metonímico do corpo materno e não como efeito de um processo metafórico em que o corpo materno interditado seria substituído por outro corpo, uma Outra mulher. ${ }^{1}$

É nesse sentido que Paulo não consegue estabelecer relações com mulheres comuns, pois estas o remetem diretamente ao corpo materno. Podemos supor que a mulher pública encarnada pela prostituta, ao colocar uma distância construída pela série de mulheres, apresenta-se então como possibilidade de encontro com o sexo feminino que não remete ao Outro primordial. Uma tentativa de Paulo de inscrever diferenciação/separação no que se apresenta indiferenciado.

No seminário A identificação (1961-1962/2003), Lacan vai dar pleno desenvolvimento à função do traço como registro específico do humano, utilizando pela primeira vez de forma sistematizada o recurso à topologia. Lacan refere-se

\footnotetext{
${ }^{1}$ É por meio da primazia do significante que Lacan busca se aproximar de Freud, propondo o inconsciente enquanto uma cadeia de significantes que se repete e insiste em outra cena, interferindo no discurso efetivo. Dentro da idéia do inconsciente estruturado como uma linguagem, Lacan vai aproximar os mecanismos de condensação e deslocamento formulados por Freud enquanto característicos das leis que regem o funcionamento do processo primário, das figuras de linguagem metáfora e metonímia. A metáfora supõe relações de similaridade e implica uma substituição significante, em que um significante advém no lugar de outro e produz um efeito de sentido. Trata-se fundamentalmente de uma substituição de posição que tem como resultado uma criação de sentido, o surgimento de uma significação. A metonímia se inscreve na ordem das relações de contigüidade e se refere à conexão entre uma palavra e outra. Designa uma coisa por meio do nome de outra que lhe serve de signo ou que guarda com ela uma relação de causa e efeito. A metonímia aponta para a remissão de um significante a outro, para o deslizamento aparentemente infinito do sujeito na cadeia significante, na qual o objeto está sempre elidido, perdido para aquele que fala. As leis de linguagem que regem o funcionamento inconsciente fazem com que a representação recalcada só possa ser evocada por meio de substituições significantes que deslizam de forma metonímica na cadeia da linguagem.
} 
às inscrições encontradas na costela de um animal morto exposta no museu de Saint Germain, uma série de pequenos bastões feitos provavelmente por um caçador para marcar os animais abatidos, para ilustrar a inscrição de uma série que funda o saber inconsciente sustentado na descontinuidade simbólica. O ato realizado pelo caçador implica um registro temporal, inaugura uma possibilidade de contagem ao introduzir uma diferença no campo do real. É a partir dessa inscrição do significante no real que o sujeito pode se contar no tempo, já que ele não está mais submerso em um presente infinito. O significante introduz uma descontinuidade em um campo que era a princípio continuidade. A partir dessa descontinuidade é possível a contagem; um antes e um depois. Essa primeira inscrição significante de uma diferença permite que o sujeito se reconheça em diferentes momentos como sendo ele mesmo, como sendo ainda ele. É nesse sentido que a inscrição do traço, a semelhança da memória posta em ato pelo jogo do Fort-da, pode ser tomada como precondição para que a representação possa ter lugar. É a partir dessa inscrição que o sujeito pode se contar como um entre outros, pura diferença entre iguais, unidade imaginária sustentada na descontinuidade do traço significante.

No entanto, podemos pensar em outra hipótese que tem efeitos completamente distintos dessa primeira hipótese sobre a prostituta como possibilidade de estabelecimento de uma série. A série aponta para o funcionamento significante do traço tomado aí como traço unário; traço distintivo que remete a outros traços e cuja relação se dá entre os traços e aponta para o funcionamento simbólico que se diferencia/separa do campo do real; campo que permanece como algo que não se pode contar. No caso de Paulo, a namorada mitológica, a noiva teológica e a esposa mística não separam/diferenciam o campo do prazer sexual do campo do gozo; campo do Outro primordial. A prostituta encarna em um só corpo todas essas mulheres e nesse sentido a série fracassa na tentativa de produzir um traço distintivo, pois remete sempre ao mesmo, ao original.

$\mathrm{Na}$ neurose, a busca pelo unário confunde-se com a busca pela origem de uma satisfação primeira, na qual o significante ficaria reduzido a um signo do objeto da satisfação. Contudo, a cada tentativa de anular o apagamento que o registro significante realizou, é de novo o apagamento que surge na repetição, é outra vez o traço que surge no lugar da coisa. No caso de Paulo, diferentemente da neurose, a mulher prostituta funciona como pura exterioridade, elemento inassimilável que remete ao signo do Outro, namorada mitológica, noiva teológica, esposa mística; figuras originárias que: conjugam origem e morte no encontro letal entre a palavra e a coisa, entre o corpo e o gozo. A exterioridade não é a alteridade sustentada na descontinuidade simbólica. Para melhor delimitarmos essa exterioridade impossível de ser assimilada pelo sujeito vamos recorrer a elementos que Lacan extrai da clínica das psicoses. 


\section{APONTAMENTOS SOBRE AS PSICOSES}

É interessante apontar que a investigação da psicose, com freqüência, passa no ensino de Lacan, pela escrita: a escrita de Marguerrite Anzieu, a quem nomeou Aimée na sua tese de doutorado "Da psicose paranóica em suas relações com a personalidade” (1932/1987), a escrita de Schreber no seminário As psicoses (195556/1985) e a escrita de James Joyce no seminário Le sinthome (1975-76/1977). Lacan vai privilegiar na sua leitura do caso Schreber a noção de estrutura e a prevalência do simbólico. Ele se preocupa em diferenciar o mecanismo em jogo na psicose, tomando como referência o complexo de Édipo enquanto estruturante do sujeito. O desencadeamento da psicose é abordado por meio da coincidência de duas quedas, a justaposição de dois furos: um no simbólico e outro no imaginário. O furo no simbólico refere-se à forclusão (Verwerfung) do significante do nome do pai, a ausência de um significante primordial que organiza a filiação do sujeito e porta a ordenação das gerações. O furo no imaginário refere-se à elisão da significação fálica que ordena as produções de sentido, a representação. Sem ter como responder tanto do ponto de vista imaginário como do ponto de vista simbólico ocorre o desencadeamento da psicose e a única resposta possível o sujeito encontra no delírio.

Neste momento de seu ensino, Lacan aborda o pai enquanto um significante. No seminário As formações do inconsciente (1957-58/1999) o pai vai aparecer como metáfora; a substituição de um significante por outro e, como toda a metáfora, engendra um sentido, uma linhagem. Mais tarde, com a introdução da topologia dos nós o pai é um nome e sustenta-se no "pelo menos três”, ou seja, o pai como nome sustenta-se a partir dos três registros; RSI e não mais prioritariamente no simbólico. Do pai como significante, passando pelo pai como metáfora e chegando ao pai como nome... Podemos extrair deste percurso de Lacan uma série de conseqüências para a clínica da psicose.

Vamos nos deter aqui no que nos interessa para melhor compreendemos essa exterioridade radical à qual o psicótico está submetido. Vamos partir da proposta freudiana de uma divisão original da experiência de realidade especialmente trabalhada no texto sobre a denegação (FREUD, 1925/1981) e da leitura de Hyppolite e Lacan (1954/1998) a partir de Hegel, filósofo que introduz a dialética da negatividade na constituição do sujeito para entender do que se trata. A denegação é uma Aufhebung (negar, suprimir, conservar, suspender) do recalque, através da qual o sujeito apresenta-se à maneira do não-ser. Trata-se de um momento mítico, uma operação lógica que funda o sujeito do inconsciente em uma espécie de continuidade moebiana entre simbólico e real. Em um primeiro momento, interior-exterior, subjetivo-objetivo estariam indiferenciados. A diferença vai ser introduzida justamente por meio da operação exercida pela denegação, que se constitui a partir de uma afirmação primordial, Bejahung, e de 
uma negação-expulsão, Ausstossung. Da afirmação primordial surge um juízo de atribuição que fornece às coisas suas qualidades e constitui-se então a distinção entre o que pode fazer parte do eu e que será introjetado (Introjezieren) pelo eu e o que pode não fazer parte do eu e será rejeitado (Verwerfung).

Trata-se aí de um eu arcaico, para o qual não há ainda nada estranho a ele; um eu corporal regulado pelas experiências de prazer-desprazer, nossos organizadores pulsionais. O eu corporal pode introjetar como próprias coisas que a princípio não fazem parte do corpo biológico, e rejeitar partes do corpo biológico como estranhas ao eu corporal. Quero dizer com isso que essas primeiras fronteiras, que traçam os limites do eu-corporal, não traçam necessariamente um corpo conforme os signos dados pela anatomia, uma vez que se trata aí de um corpo representado. A afirmação (Bejahung) constitui então o campo do eu prazer e também o campo do não eu desprazer, campo do objeto como resto, como estranho. Através da negação (Ausstossung), constitui-se um juízo de existência que fornece orientação na construção da realidade, a partir da relação entre a representação e a percepção, cuja prova de realidade é baseada na possibilidade de reencontrar o objeto (FREUD, 1925).

Podemos supor, ao acompanhar a leitura de Didier-Weill (1997), que na origem o sujeito que ainda não está lá, mas está por vir, diz sim (Bejahung) a alguma coisa que ainda não sabe o que é, mas que faz apelo ao sujeito incipiente. Ao responder "sim” ao apelo do Outro do qual ainda não é separado, o sujeito tem acesso a uma primeira simbolização que nomeia o real que o sujeito rejeitou (Verwerfung), para um primeiro exterior, ou seja, um real foracluído do simbólico. Por meio dessa primeira nomeação na qual o sujeito responde sim (Bejahung) ao apelo do Outro, inscreve-se no real um traço que não remete a nada a não ser a ele mesmo, ao qual Lacan faz corresponder o traço unário. Não se trata ainda de um significante, pois para que ele funcione como tal e represente o sujeito para outro significante é necessária uma segunda operação, que vai dar origem ao saber inconsciente, colocando o traço em relação a outros traços.

Após a primeira operação inaugurada pela Bejahung, segue-se uma segunda operação introduzida pela negação (Ausstossung). Essa segunda operação vai ressignificar a Bejahung original e possibilitar outra relação entre simbólico e real que não é igual àquela primeira de exclusão radical. Trata-se justamente do recalque originário introduzido a partir da negação (Ausstossung) do traço unário. A Bejahung é um sim do sujeito à palavra do Outro que o marca. Em seguida, ele diz não ao Outro (Ausstossung), esquecendo que a palavra vem do Outro e, desse modo, torna-se proprietário dessa palavra. O recalcamento permite ao sujeito falar sem ser afetado pelo lugar de onde vem a palavra. Segundo Didier-Weill: 
“A diferença fundamental entre o ato do par Introjezieren-Verwerfung e do par BejahungAusstossung advém de que o primeiro tem por efeito por em perspectiva um limite entre o simbólico introjetado e o real rejeitado, enquanto que o segundo tem por efeito produzir um simbólico posto em continuidade moebiana com o real." (1997, p.297)

Nesse encontro entre o mais íntimo e o mais exterior, o sujeito se constitui em uma continuidade moebiana entre íntimo e exterior e não por uma descontinuidade dentro fora. ${ }^{2}$ Enquanto pelo sim-não da Bejahung-Ausstossung, uma parte do sujeito desaparece com o consentimento inconsciente do sujeito, de tal forma que essa desaparição se traduz pela aparição de um espaço ex-timo; por outro lado pelo não absoluto do ato de Verwerfung o significante do Nome-do-Pai, banido do simbólico, não desaparece, mas reaparece em um lugar que se pode definir como exterior ao sujeito. É a essa exterioridade que estamos nos referindo no caso de Paulo. A diferença entre o "não" associado a um "sim" que corresponde ao recalque, e o "não" absoluto que corresponde a Verwerfung é que o "não" do recalque implica uma rejeição decorrente da relação do sujeito à linguagem, pois nesta o real fica negado por uma Aufhebung. Já o "não” da Verwerfung é associado por Lacan no seminário sobre as psicoses à estrutura da psicose porque foraclui-rejeita o significante do Nome do Pai do campo do simbólico:

"O que cai sob o golpe do recalque retorna, pois o recalque e o retorno do recalcado são apenas o direito e o avesso de uma mesma coisa. O recalcado está sempre aí, e ele se exprime de maneira perfeitamente articulada nos sintomas e numa multidão de outros fenômenos. Em compensação, o que cai sob o golpe da Verwerfung tem uma sorte completamente diferente (...) tudo o que é recusado na ordem simbólica, no sentido da Verwerfung, reaparece no real.” (LACAN, 1955-19561985, p.21)

\section{O ARTÍFICE DA PASSAGEM}

Podemos voltar à encenação corporal que convoca Paulo a tocar os símbolos e proteger o corpo do toque dos outros corpos. Segundo Didier-Weill (1997),

\footnotetext{
${ }^{2}$ A utilização da topologia pela teoria psicanalítica permite ultrapassar oposições que por tradição organizam nossas representações como a oposição entre o todo e a parte, o interior e o exterior, o continente e o conteúdo, o simétrico e o dessimétrico. A banda de Moebius é uma tira de papel formada a partir de uma torção de superfície em seguida unida pelas pontas que se torna uma superfície de uma só face. Assim Lacan utiliza a banda de Moebius com o objetivo de demonstrar que o sujeito enquanto efeito da articulação entre dois significantes, é sempre fugaz e sem lugar fixo pois ela permite uma mostração da continuidade dentro-fora na qual se institui o sujeito do inconsciente. No decorrer de seu ensino Lacan preocupa-se em diferenciar o sujeito do Eu. O Eu se constitui a partir da dialética especular e sustenta-se na ilusão da unidade e da permanência.
} 
a proibição do toque visa proteger o humano do real que emerge através da barreira porosa do interdito simbólico e que não se confunde com o retorno do recalcado submetido às leis da descontinuidade simbólica, mas remete a essa exterioridade radical à qual podemos associar a emergência do real. O que ocorre na emergência do real é a indiferenciação entre real e simbólico, em que o real vem contaminar o simbólico promovendo indiferenciação entre: o informe e a forma, o ilimitado e o limitado, o inumano e o humano. O contato com o real rejeitado do simbólico macula o corpo e desmancha as bordas corporais sustentadas na descontinuidade simbólica. Ocorre aí uma mistura entre o real e o simbólico, entre o contínuo e o descontínuo. Podemos supor, então, que o tocar/ser tocado coloca em causa uma possibilidade de defesa contra a contaminação, a indiferenciação entre símbolo e corpo, quando Paulo tem seu corpo invadido por essa indiferenciação entre o simbólico e o real e sua integridade corporal é ameaçada.

Curiosa escolha a de Paulo que encontra uma possibilidade de simulação/ dissimulação do eu ao apresentar-se à mulher como topógrafo. Esconderijo especular que enraíza o lugar na dissimulação oferecida pela unidade da imagem e não na descontinuidade simbólica. Imagem que se desfaz no encontro com o sexo feminino. No seminário As psicoses (1955-1956/1985) Lacan utiliza a metáfora de um banquinho de três pés para referir-se à fragilidade desse modo de situar-se na realidade. Trata-se do que ele chamou de bengalas imaginárias, identificações com personagens que oferecem modelos de comportamento: como se comportar como homem ou como mulher. Por meio da imitação da imagem do semelhante, do par que lhe serve de muletas, o sujeito sustenta-se em um jogo de faz-deconta, vivendo em conformidade com os modelos que lhe são propostos pelo social até que um terceiro, um ímpar, vem desfazer seu arranjo.

Podemos pensar aqui em uma analogia entre essa identificação puramente adesiva à imagem do outro e os fenômenos de mimetismo encontrados no reino animal. Para o animal não existe a alteridade simbólica, apenas a continuidade entre a imagem e o objeto. Nesse caso, as bengalas imaginárias que sustentam o psicótico na realidade são precárias e não garantem a permanência do registro do eu na ausência da imagem do outro na qual se sustenta. No seminário Le sinthome (1975-76/1977) Lacan pinça no romance Retrato de um artista quando jovem de James Joyce um acontecimento narrado por Stephen Dedalus que remete à perda do suporte identificatório do corpo e, conseqüentemente, a uma desrealização do corpo. Trata-se da surra que Stephen recebe de alguns colegas por não compartilhar das mesmas preferências literárias que eles: Enquanto regressava cambaleando pela rua Stephen sentira que uma certa força o despojava daquela súbita onda de raiva, tão facilmente quanto um fruto é despojado de sua casca mole e madura (JOYCE, 1967, p.45). 
A partir desse fragmento do texto de Joyce, Lacan conclui nesse mesmo seminário, que essa maneira de deixar cair o que concerne à imagem do corpo próprio é que é suspeita para um analista. Stephen não perde apenas o suporte da imagem corporal, mas também o suporte oferecido pela leitura, uma vez que as referências literárias não lhe servem mais. No entanto, a surra não resulta em uma crise de despersonalização em que o suporte corporal se esvai aos pedaços. Talvez porque essa queda do que concerne ao corpo próprio incida não apenas sobre o corpo de Joyce, mas principalmente sobre o corpo da língua, sobre o texto que Joyce vai compondo e que é cada vez mais esvaziado de personagens e de consistência imaginária.

A escrita de Joyce transforma a própria linguagem manipulando as letras em um jogo que vai do esvaziamento ao excesso de sentido, o que leva a um rompimento da tradição da escrita enquanto representação. Sobretudo a partir de Ulisses, Joyce vai se dedicar a um trabalho exaustivo sobre a linguagem, trabalhando as palavras uma a uma. Elas são decompostas, cortadas, grudadas, rasuradas, revelando o jogo entre a letra (letter) e o lixo (litter) já apontado por Lacan no texto sobre a carta roubada (1956/1998). A analogia é retomada por Lacan logo no início de Lituraterra (1971/2003) e evocada no seminário Mais ainda (1972-73/1985) com a aproximação entre o ato de publicar e o ato de jogar os restos no lixo o que Lacan escreve através de um neologismo: poubellication, traduzido na versão brasileira como publixo. O jogo entre a letra e o lixo aponta a materialidade da letra e remete à aproximação, cada vez mais evidente no decorrer do ensino de Lacan, entre a letra e o objeto.

Estratégia interessante cujos ecos encontramos na escrita de Paulo. A escrita de Paulo promove uma espécie de desrealização do corpo e seu trabalho de rasura da letra visa exatamente a esse deslocamento da letra ao lixo que fura a representação ao apagar a função mensageira da linguagem. Do lugar da produção/ escritor podemos supor que Paulo não se localiza a partir de um espaço topográfico sustentado apenas nas referências especulares; espaço imaginário em que a gestalt do corpo do semelhante é tomada como o modelo do conhecimento dos objetos da realidade; espaço de formas planas em conformidade com a geometria euclidiana. Por meio de seu trabalho com a letra, Paulo cria um espaço topológico sustentado na subtração da imagem. ${ }^{3}$ Vejamos do que se trata.

\footnotetext{
${ }^{3}$ Topografia e topologia referem-se a relações de lugares. No entanto, estamos supondo que a topografia sustenta lugares a partir da lógica dual inaugurada pelo estádio do espelho no qual o sujeito projeta sua imagem no exterior, no outro, e tem acesso a uma primeira representação do eu. A imagem do eu torna-se a medida de todos os objetos que compõem a realidade do sujeito, uma realidade homogênea ao eu, em que o outro e o objeto são equivalentes. Dentro dessa concepção, o objeto refere-se ao objeto do conhecimento; objeto que
} 
Em determinado momento, Paulo diz que o exterior fechou-se para ele, não havia nenhuma possibilidade de lugar no campo social — seja no que se refere ao trabalho, às relações familiares ou relações afetivas. Não havia nenhuma possibilidade de se fazer representar a partir dos laços sociais e então ele se volta para o interior. É nesse espaço chamado interior, ou ainda espiritual, que Paulo tenta inscrever um registro. Na verdade, não se trata nem de interior, nem de exterior, mas do espaço presentificado pelo canudo, superfície que contém o vazio. Assim, abandona a imagem do topógrafo que não se sustenta no encontro amoroso e revela outra posição; Paulo é aquele que realiza o ato de passagem da substância à essência, da matéria ao espírito, do material ao imaterial, através das rasuras feitas com sua caneta. Por meio desse ato ele faz surgir outro espaço chamado por ele de dimensão espiritual.

Nesse outro espaço tudo o que existe lhe pertence, tudo pode ser conservado e, no entanto, nada pode ser tocado. Ao submergirem, as letras desaparecem para aparecerem em outro lugar e, dessa forma, Paulo apropria-se do que elas simbolizam. O mesmo acontece com as imagens que assinala e com os restos que recolhe. Tudo o que é esvaziado de sua "substância” passa a pertencer-lhe. Ele conserva a mulher amada a partir do desaparecimento de sua imagem. Existe aí uma espécie de subtração da imagem do corpo. O mesmo pode ser pensado em relação ao desaparecimento das letras que, em um primeiro tempo do trabalho de Paulo, eram rasgadas, e que hoje são completamente riscadas, ou seja, têm seu corpo tipográfico rasurado e sua possibilidade de leitura literalmente apagada.

Ainda do lugar da produção/escritor, podemos nos perguntar sobre a função do canudo/bomba, posto para circular por Paulo no espaço público. Podemos supor que ele delimita um espaço furado, superfície topológica; espaço tridimensional. O canudo, objeto inventado, é nomeado por Paulo bomba de efeito moral. Bomba que só é lançada em alvos aleatórios. No entanto, já destacamos que os alvos/público não são tão aleatórios assim, visto que seguem a regra de nunca se repetirem. Podemos supor, então, que a partir dessa regra Paulo tenta estabelecer certa ordenação/diferenciação no espaço; o estabelecimento de uma fronteira simbólica. É assim que o alvo/endereçamento surge como possibilidade de introduzir uma diferença/descontinuidade no real. Nesse sentido o canudo teria aí uma função significante? Vamos nos remeter à fobia de Hans, pois ela

se funda em uma concepção narcísica do objeto e se diferencia do objeto a; objeto parcial e não narcísico. A realidade na qual circulam os objetos do conhecimento sustenta-se nas referências imaginárias; alto/baixo, esquerda/direita, simétrico/dessimétrico etc. Já a topologia sustenta lugares na descontinuidade simbólica e na continuidade moebiana entre íntimo e exterior que constitui o espaço ex-timo; a borda em torno do vazio a partir da qual o sujeito constrói suas fronteiras simbólicas e imaginárias: eu/outro, sujeito/Outro dentro/ fora, contínuo/descontínuo, dia/noite, masculino/feminino, etc. 
nos oferece elementos para pensar essa questão. Segundo Corrêa (2003), o pavor cria fronteiras e a angústia é um sinal que marca no espaço zonas que não podem ser ultrapassadas. O medo de Hans do cavalo substitui o medo que não surge da palavra do pai e, assim, os cavalos de angústia balizam o espaço de sinais que fazem suplência a falta do interdito simbólico:

"O complexo do cavalo, diz Freud - representa o elemento substituível, permutável, separável. É em virtude desse papel estruturante do sintoma, deste laço entre imaginário, simbólico e real, que Freud ajudou a fobia a se expandir através da única intervenção direta que fez a Hans, anunciando-lhe seu mito, o mito de Édipo.” (CORRÊA, 2003, p.71)

Na formação do sintoma fóbico, o objeto pai é substituído pelo objeto animal e a resposta fóbica é ela mesma uma metáfora, uma vez que faz do objeto fóbico um objeto posto em função significante. Com a instauração de uma cifra que representa não mais o objeto e sim sua representação, a resposta fóbica barra o objeto como referente. Nesse sentido, a metáfora barra o objeto, simbolizando-o. No caso de Paulo, o canudo que circula no espaço público não remete à formação de um substituto, um objeto posto em função significante que se desloca no espaço inscrevendo fronteiras e remetendo o sujeito para a existência de um espaço Outro, como é o caso do cavalo para Hans. O canudo, superfície que contém o vazio, remete à letra na sua função litoral; ao lugar vazio do objeto; furo que não produz borda no saber. A partir dessa hipótese em que tomo a escrita de Paulo como referida à letra na sua função litoral, a escrita surge como possibilidade de conjugar/distinguir o que estava radicalmente separado/misturado pela Verwerfung: os registros do simbólico e do real. No entanto, diferente da fobia de Hans onde o sintoma amarra real, simbólico e imaginário, a escrita de Paulo aponta para um laço entre real e simbólico e deixa de lado o imaginário.

Do lugar do público/leitor podemos supor que o canudo de Paulo é a própria encarnação da letra na sua relação ao furo. Furo que incide no semblante oferecido pelo significante, pela linguagem. O objeto-canudo posto para circular no espaço público por Paulo não fixa um sentido, mas provoca uma espécie de curto-circuito na função mensageira da linguagem. Trata-se de uma escrita que rompe as referências que organizam a nossa percepção espacio-temporal e a nossa representação, fazendo emergir um objeto, uma presença que faz furo no saber. Não se trata apenas de uma suspensão do saber, ou de um não saber, mas do aparecimento de um furo no saber; furo que organiza o saber, mas que freqüentemente não se presentifica, não é especularizável, e assemelha-se ao umbigo dos sonhos, ponto em que o conhecido se enlaça ao desconhecido. 
A presentificação desse furo encarnado pelo objeto que Paulo faz circular no espaço público provoca no público/leitor uma súbita desorganização das referências, fazendo emergir o espanto no lugar do já conhecido; e assim permanece como objeto que não é totalmente assimilado pelo campo discursivo, mas que também não é de todo rejeitado por esse campo, já que provoca efeitos na realidade discursiva. Objeto que, tal qual a letra-litoral, aponta a ausência de uma medida comum entre os campos heterogêneos que constituem o humano.

Do lugar da produção/escritor podemos supor que a regra de não repetir o alvo, colocada por Paulo remete outra vez à defesa contra a indiferenciação entre o símbolo e o corpo; funda assim um espaço sustentado em proibições que visam estabelecer barreiras contra o real que ameaça invadir o corpo. Nesse sentido, as barreiras que introduzem diferença no espaço são sustentadas pelo ato contínuo de Paulo; ato que implica o movimento incessante do corpo e a fixidez dos alvos. O ato através do qual Paulo endereça-se ao público/alvo introduzindo aí uma diferença visa à descontinuidade entre o corpo e o símbolo, entre o sujeito e o Outro; contudo, essa descontinuidade só se produz a cada vez que o ato é realizado.

\section{A RASURA DA LETRA}

Podemos supor, do lugar da produção/escritor, que um dos efeitos da letra no trabalho de Paulo é a subtração do corpo por meio de um trabalho de rasura da letra, uma espécie de encobrimento da letra. Em Lituraterra (1971/2003), Lacan, à maneira de Joyce, joga com as assonâncias entre literatura e litura. Da janela do avião que sobrevoa a planície siberiana, Lacan distingue, por entre as nuvens, o escoamento das águas na planície desértica. O escoamento das águas na planície revela a conjunção do traço primário com aquilo que o apaga, mas aí se marcam dois tempos:

"O escoamento é o remate do traço primário e daquilo que o apaga. Eu o disse: é pela conjunção deles que ele se faz sujeito, mas por aí se marcam dois tempos. É preciso, pois, que se distinga nisso a rasura." (LACAN, 1971/2003, p.21)

Lacan aproxima o primeiro tempo à arte da caligrafia, que realiza o casamento da letra com a pintura, enquanto litura pura:

"Rasura de traço algum que seja anterior, é isso que do litoral faz terra. Litura pura é o litoral. Produzi-la é reproduzir essa metade ímpar com que o sujeito subsiste. Esta é a façanha da caligrafia. Experimentem fazer essa barra horizontal que é traçada da esquerda para a direita, para figurar com um traço o um unário como caractere, e vocês levarão muito tempo para descobrir com que apoio ela se 
empreende, com que suspensão ela se detém. A bem da verdade, é sem chances para um ocidentado." (Ibid., p.21)

A rasura-litura designa aí uma função paradoxal: aponta ao mesmo tempo o gozo que se revela na possibilidade de traçar de uma só vez esse traço primeiro de identificação plena e a impossibilidade de traçá-lo. Acontece que a rasura e a caligrafia já remetem a uma perda, um apagamento, pois a pegada do passo na areia é marca do rastro do objeto e não o objeto mesmo. O segundo tempo é aquele do apagamento que coloca o traço em relação a outros traços, apagando a relação entre a marca e o objeto/referente; tempo que implica a leitura que dá nome aos signos que traçam o real. Segundo Lacan (1961-62/2003), a leitura ao mesmo tempo precede e funda o escrito e faz do traço-marca um traço significante. É aí que Lacan faz intervirem as nuvens como função de semblante do significante:

"O que se revela por minha visão do escoamento, no que nele a rasura predomina, é que, ao se produzir por entre as nuvens, ela se conjuga com sua fonte, pois que é justamente nas nuvens que Aristófanes me conclama a descobrir o que acontece com o significante: ou seja, o semblante por excelência, se é de sua ruptura que chove, efeito em que isso se precipita, o que era matéria em suspensão." (LACAN, 1971/2003, p.22)

A rasura que se conjuga com sua fonte: o significante que revela então sua função prevalente, a de ser semblante que ao se dissolver aponta para o informe, o imundo do gozo, e que Lacan nomeia 'ravinamento' das águas; as marcas, os sulcos no real. Nesse sentido, é a linguagem que lê as marcas no real e, nomeando-as, enumerando-as e conectando-as a outros significantes faz surgir a bateria significante. Assim, o que precede a escrita: marca, rastro, signo é lido com a linguagem e aí transformado em escrita. A letra serve então de suporte ao significante, e o discurso enlaça-a na rede do semblante. O discurso possibilita que o sujeito esteja "apoiado em um céu constelado e não apenas no traço unário” (Ibid., p.24).

Como já apontamos, a escrita de Paulo privilegia a função da rasura e nesse sentido parece aproximar-se desse segundo tempo descrito por Lacan. No entanto, se a letra utilizada na sua função de rasura promove uma subtração do corpo, o toque vai colocar em causa uma espécie de encenação do corpo. Podemos supor, então, que, se a rasura tivesse o efeito desejado - a inscrição de um traço simbólico a partir do qual Paulo pudesse se representar e se singularizar, sustentando as bordas corporais na descontinuidade simbólica, na cadeia do saber inconsciente - a encenação do corpo, colocada em causa no ato de tocar e impedir o toque do outro, seria desnecessária. 
A rasura enlaça criação e origem, mas a origem, graças à criação, permanece exilada nesse interior excluído que nos é tão próximo e ao mesmo tempo tão distante. Certamente podemos dizer que Paulo cria, mas a rasura, embora seja tomada aí como o motor de sua criação, não permite a instauração do saber inconsciente sustentado na descontinuidade simbólica, assim como não permite que sua insígnia funcione como assinatura. A assinatura é para Lacan o traço apagado: um signo que anulado funciona como assinatura, como a cruz que simboliza a barra. A insígnia por meio da qual Paulo tenta representar-se simboliza o vôo de um pássaro e, nesse sentido, podemos dizer que expressa o desejo de alçar vôo pela via do significante, alcançar a imaterialidade do corpo deixando para trás as amarras da origem.

Recebido em 30/5/2007. Aprovado em 14/8/2007.

\section{REFERÊNCIAS}

CORRÊA, I. (2003) A psicanálise e seus paradoxos. Recife: Centro de Estudos Freudianos do Recife/Ágalma.

COSTA, A. M. M. (2003) Tatuagens e marcas corporais. São Paulo: Casa do Psicólogo.

DIDIER-WEILL, A. (1997) Os três tempos da lei. Rio de Janeiro: Jorge Zahar.

FREUD, S. (1981) Obras completas. Madrid: Biblioteca Nueva.

(1908) Teorias sexuales infantiles. Tomo II.

(1909) Analisis de la fobia de un niño de cinco años (caso Juanito). Tomo II.

(1925) La negación. Tomo III.

JOYCE, J. (1967) Retrato de um artista quando jovem. Lisboa: Livros do Brasil.

(1996) Ulisses. Rio de Janeiro: Civilização Brasileira.

LACAN, J. (1932/1987) Da psicose paranóica em suas relações com a personalidade. Rio de Janeiro: Forense Universitária.

. (1954/1998) "Resposta ao comentário de Jean Hyppolite sobre a 'Verneinung' de Freud”, in Escritos. Rio de Janeiro: Jorge Zahar.

(1955-1956/1985) O Seminário livro 3, As psicoses. Rio de Janeiro: Jorge Zahar.

. (1956/1998) "O seminário sobre A carta roubada", in Escritos.

Rio de Janeiro: Jorge Zahar.

. (1957-1958/1999) As formações do inconsciente. Rio de Janeiro: Jorge Zahar.

(1958/1998) "Juventude de Gide ou a letra e o desejo", in Escritos. Rio de Janeiro: Jorge Zahar.

(1961-1962/2003) A identificação. Publicação para circulação

interna. Recife: Centro de Estudos Freudianos de Recife. 
(1964/1998) O seminário livro 11, Os quatro conceitos fundamentais da psicanálise. Rio de Janeiro: Jorge Zahar.

. (1968-1969) De um Outro ao outro. Publicação para circulação interna. Recife: Centro de Estudos Freudianos de Recife.

(1972-73/1985) O seminário livro 20, Mais ainda. Rio de Janeiro: Jorge Zahar.

(1975-76/1997) Le seminaire, Livre 23, Le sinthome. Ornicar? Revue du Champ Freudien, n.6-11. Paris.

. (1971/2003) "Lituraterra", in Outros escritos. Rio de Janeiro: Jorge Zahar.

MANDIL, M. (2003) Os efeitos da letra; Lacan leitor de Joyce. Belo Horizonte: Contra Capa.

MILNER, J-C. (1996) A obra clara; Lacan, a ciência e a filosofia. Rio de Janeiro: Jorge Zahar.

Andrea Menezes Masagão

andreamasagao@uol.com.br 